Yılmaz Hiğde, A., Baştuğ, M. ve Cihan, H. (2020). Okul öncesi dönem ebeveynlerinin ev okuryazarlığı yaşantılarının incelenmesi. Ana Dili Ĕ̆itimi Dergisi, 8(2), 628-645.

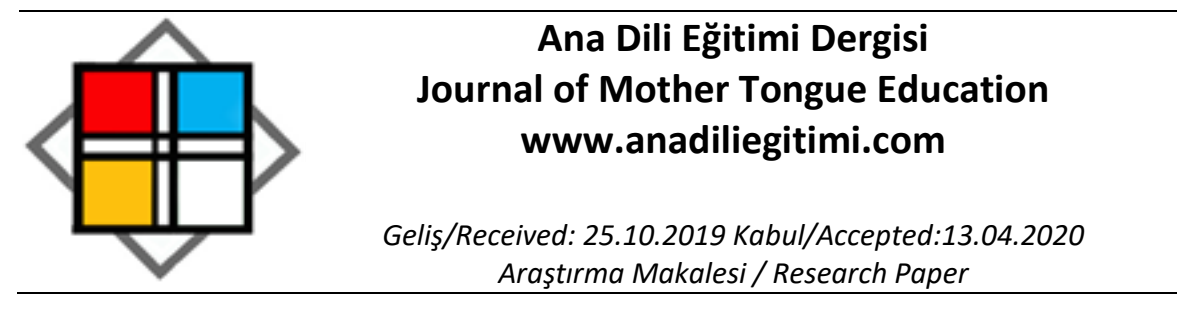

\title{
Okul Öncesi Dönem Ebeveynlerinin Ev Okuryazarlığı Yaşantılarının İncelenmesi *
}

\author{
Aylin YILMAZ HIĞDE** \\ Muhammet BAŞTUĞ $\breve{H}^{* *}$ \\ Halime CIHAN ${ }^{* * * *}$
}

\begin{abstract}
Öz
$\mathrm{Bu}$ çalışmanın amacı okul öncesi dönemde çocuğu olan ebeveynlerin ev okuryazarlığı yaşantılarının incelenmesidir. Araştırma durum çalışmasıdır. Araştırmaya alt, orta ve üst sosyoekonomik düzeyden 23 ebeveyn katılmıştır. Sosyoekonomik düzey belirlenirken ailenin ortalama aylık geliri, anne ve babanın eğitim düzeyleri ve meslek grupları dikkate alınmıştır. Veriler yarı yapılandırılmış görüşme soruları ile toplanmıştır. Tümevarımsal analiz kullanılarak analiz edilmiştir. Yapılan analizler sonucu elde edilen bulgulara göre, alt sosyoekonomik düzeyde yer alan ebeveynlerin, çocuk okul öncesi eğitime başlayana kadar okuryazarlık ile ilgili bilinçli ev etkinliklerine yer vermedikleri söylenebilir. Çocuk okula başladığında ise bu etkinlikler sadece ödevler ile sınırlı kalmıştır. Orta ve üst sosyoekonomik düzeyde ise ev okuryazarlığı aktivitelerinin arttığı, erken yaştan itibaren çocuğa etkileşimli olarak kitaplar okunduğu, evde kitaplık bulunması durumunun arttığı görülmüştür. Sosyoekonomik düzey arttıkça ev okuryazarlığı aktiviteleri aracılığıyla, okul ve ev arasında işbirliğine dayalı bir yaklaşımın benimsendiği söylenebilir.
\end{abstract}

Anahtar Kelimeler: Ev okuryazarlığı, erken okuryazarlık, ebeveyn deneyimi, durum çalışması

\begin{abstract}
An Investigation of Home Literacy Experiences of Preschool Parents
Abstract

This study aims to examine the home literacy experiences of parents who have children in preschool period. It is designed as a case study. 23 parents with lower, middle and higher socioeconomic status participated in the study. Data were collected through semi-structured interview questions. Findings of the study revealed that parents having lower socioeconomic status did not perform conscious home activities related to literacy until their child started preschool education. For parents having middle and higher socioeconomic status, it was observed that activities of home literacy such as interactive book reading with the child from an early age increased. As a conclusion, it can be concluded that as the socioeconomic status increases, a collaborative approach between school and home is adopted through home literacy activities with children at home.
\end{abstract}

Keywords: Home literacy, early literacy, parental experience, case study

\section{Giriş}

Okuryazarık, insanların düşünmesini, iletişim kurmasını, toplumu araştırmasını ve etkileşim kurmasını sağlayan edinilmiş, sosyal olarak oluşturulmuş ve yönlendirilmiş bir araçtır (Van Vechten,

\footnotetext{
* Çalışma, 18-22 Nisan 2018'de 27. Uluslararası Eğitim Bilimleri Kongresi'nde sözlü bildiri olarak sunulmuştur.

** Doktora Öğrencisi, İstanbul Üniversitesi-Cerrahpaşa, Hasan Ali Yücel Eğitim Fakültesi, Temel Eğitim, İstanbul, aylinnyilmz@gmail.com, ORCID: 0000-0001-9220-6847

*** Doç. Dr., İstanbul Üniversitesi-Cerrahpaşa, Hasan Ali Yücel Eğitim Fakültesi, Temel Eğitim, Sınıf Öğretmenliği, İstanbul, mbastug@istanbul.edu.tr, ORCID: 0000-0002-5949-6966

**** Sınıf Öğretmeni, Emrullah Turanlı illkokulu, Ümraniye, İstanbul, halimeogretmen@gmail.com, ORCID: 00000001-5916-7540
} 
2013). Okuryazar olmak, bir dile hakim olma, metinlere maruz kalma, çevresel etkiler, bilişsel yetenek ve diğer birçok faktörü içeren çok yönlü, yaşam boyu süren bir süreçtir (Van Vechten, 2013). Bu çalışmaya yön veren okuryazarlı̆ın tanımı, toplumun rollerine, kültürel farklılıklara dayalı olarak sosyokültürel açıdan ele alınmıştır. Larson ve Marsh (2005), sosyokültürel ortam içinde çocuğu, "bilginin kültür etkisiyle inşa edildiği ve sürekli değiştiği bir ortamdaki topluluğun, aktif bir üyesi" olarak tanımlamaktadır. Bu tanımdan hareketle, çocuğun içinde büyüdüğü çevrenin okuryazarlık deneyimlerini yaşadığı ilk yer olduğu söylenebilir. Okuryazarlık becerilerinin örtük olarak kazandırılması, çocukların bir sınıfa ayak basmasından yıllar önce başlar. Erken yaşlardan itibaren okuryazarlık ve dil gelişiminde desteklenmeyen çocuklar okula başlamadan önce akranlarının gerisinde kalabilirler (Van Vechten, 2013). Heath (1982), Goodman (2001) gibi önde gelen araştırmacı ve dilbilimcilerin çalışmaları, bir çocuğun bulunduğu ortamın yazılı ve sözlü dil becerileri üzerinde önemli bir etkiye sahip olduğu görüşünü desteklemektedir.

Ev, birçok çocuk için dil ve okuryazarlık becerilerinin temellerinin atıldığı yerdir (Van Vechten, 2013). Evde metinlere maruz kalma, kuşaklar arası yapılan ortak okuryazarlık faaliyetleri ve okumayazmaya hazırlık çalışmaları, etkili ev okuryazarlığı ortamları ile mümkün olabilmektedir. Ev okuryazarlığı çeşitli şekillerde tanımlanmış ve araştırmalara konu olmuştur. Bu tanımlardan en yaygın olarak ev okuryazarlığı, evde çocuğun maruz kaldığı kitapların sayısı, evde paylaşılan kitap okuma ve diğer okuryazarlık faaliyetlerine harcanan süredir (Leseman ve de Jong, 1998). Burgess, Hecht ve Lonigan (2002) ev okuryazarlık ortamını, çocuklara çeşitli kaynaklar aracılığıyla sunulan fırsatlar ve bu fırsatların sunulması için ebeveynin sahip olması gereken, yetenek, beceri ve eğilimler olarak açıklamışlardır. Bu tanımda araştırmacılar, ebeveynin sosyoekonomik düzeyi, eğitim düzeyi, mesleği, okuma-yazma sürecine yönelik tutumu ve dil becerisini temel almışlardır. Ebeveynler tarafından gerçekleştirilen bilinçli okuryazarlık aktiviteleri, paylaşımlı kitap okuma, kafiye oyunları oynama şeklindeyken, formal olmayan okuryazarlık aktiviteleri ise ebeveynin gazete, kitap, dergi okuması ya da eğitim amacı gütmeden izlediği programlardır (Burgess, Hecht ve Lonigan, 2002; Senechal ve LeFevre, 2002, Britto, 2001). Kirby ve Hogan (2008) 'a göre, ev okuryazarlı̆ı̆ın önemli olarak görülmesinin nedenlerinden birincisi, ev okuryazarlık ortamının çocukta bir "okuma kültürü" oluşturmasıdır. Çünkü ev okuryazarlık ortamının sağlanması ile çocuklar kitaplara aşina bir ortamda büyür ve ebeveynlerinin okumalarına sıklıkla şahit olur. Böyle bir ortamda büyüyen çocukta okuma kültürünün oluşması beklenir. Ev okuryazarlığı ortamının önemli görülmesinin ikinci nedeni ise ev ortamının - hem okuryazarlık hem de sözlü aktiviteler yoluyla - çocukların okuma-yazma öncesi becerileri kazanmasına katkıda bulunmasıdır. Üçüncü neden ise, ev ortamı çocuğa harf bilgisi, kelime tanıma veya kelime kod çözme gibi temel okuryazarlık becerileri sağlayabilir. Ev okuryazarlığı ile bir okuma kültürü oluşturmak, dil becerileri için bir temel oluşturmaya yardımcı olur. Böylelikle okuryazarlık gelişimi için önemli bir adım atılmış olur.

Alan yazında ev okuryazarlığı deneyimleri kelime bilgisi, kavramsal bilgi ve dil anlama becerilerinin gelişimi ile ilişkili bulunmuştur (Beals, De Temple ve Dickinson, 1994; Dickinson ve Tabors, 1991; Leseman, 1993; Watson, 1898). Evde çocuğa etkileşimli olarak kitap okunması, fonemik beceriler, kavram bilgisi, dil kullanımı ve okumaya karşı tutum üzerinde olumlu etkiye sahiptir (Dickinson ve Tabors, 1991; Mason, 1992; Wagner, Torgesen ve Rashotte, 1994; Warren-Leubecker ve Carter, 1988; Wells, 1985a, 1985b). Ayrıca, ev okuryazarlığı yaşantılarının okulda okuryazarlık başarısında etkili olduğu bulunmuştur (Mason, 1992; Purcell-Gates \& Dahl, 1991; Wells, 1985b). Bingham (2007) "ev okuryazarlığı ortamının, çocukların alıcı dil becerileri ve okuma davranışlarının önemli bir yordayıcısı olduğunu" ileri sürmektedir (s. 42).

Sosyoekonomik düzeyin evdeki okuryazarlık ortamının niteliği ve evde sağlanan okuryazarlık materyalleri üzerinde önemli bir rolü vardır (Akyüz, 2016). Burgess, Hecht ve Lonigan (2002) ev okuryazarlığı aktivitelerinde ailenin sosyoekonomik düzeyi, eğitim düzeyi gibi faktörlerin önemli olduğunu belirtmiş̧ir. Ülkemizde yapılan araştırmalarda da benzer şekilde sosyoekonomik düzeyi yüksek olan ailelerin ev okuryazarlık aktivitelerine daha sık yer verdikleri bulunmuştur (Ergül, Sarıca, Akoğlu ve Karaman, 2017; Özbek Ayaz, 2015). Otto'ya göre (2008), sosyoekonomik durumları düşük olan birçok çocuk için ev ortamı, okuryazarlık gelişimi için yeterli bir ortam sağlamayabilir. Heath (1982), bir çocuğun kültürünün ve ailesinin bulunduğu sosyoekonomik düzeyin çocuğun kitaplarla 
ilişkisini (veya eksikliğini) nasıl etkilediğini ve bunun doğurduğu sonuçları araştırmıştır. Benzer şekilde, Van Vechten (2013) düşük sosyoekonomik düzeydeki bir çocuğun ev okuryazarlığı ortamının okuryazarlık deneyimleri üzerindeki etkisini ortaya çıkarmayı amaçlamıştır. Leseman ve de Jong (1998) çalışmalarında ev okuryazarlı̆ının sosyoekonomik, kültürel ve etnik faktörlerden güçlü bir şekilde etkilendiği sonucuna ulaşmışlardır. Van Vechten (2013), düşük sosyoekonomik düzeydeki ailelerin ev okuryazarlığı ortamının çocuklar üzerindeki etkisini incelemiştir. Çalışmanın sonucunda sosyoekonomik düzeyi düşük evlerde okuyan öğrencilerin, okuma seviyelerinin sınıf ortalamasının gerisinde olduğunu, okuryazarlık ilgilerinin ve derse katılımlarının sınırlı olduğunu bulmuşlardır.

Bir çocukta erken okuryazarlık becerilerinin gelişimi okula başlamasından çok önce gerçekleşir (Van Vechten, 2013). Çocuklar okula başlayana kadar ev ortamında kazandıkları okuryazarlık becerileri aynı olmayabilir. Çoğu zaman öğretmenler, öğrencilerin aynı okuryazarlık bilgisi temeline sahip bir biçimde okula başladığını varsaymaktadır. Bu çalışmada ev okuryazarlığı ortamlarının sosyoekonomik düzeye göre farklılaşıp farklılaşmadığı araştııılmıştır. Bu araştırmanın, öğretmenlere sosyoekonomik düzeye göre öğrencilerin geçmişleri ve bu öğrencilerin okuma-yazma sürecinden önce okula nasıl bir ev ortamından geldikleri hakkında bilgi vereceği düşünülmektedir. Ev okuryazarlığının bağlamsallığı kapsamında, bu çalışma var olan durumu ortaya koymayı ve bu alandaki boşluğun bir kısmını kapatmayı amaçlamaktadır. Bu çalışmada araştıılan konu önemlidir; çünkü öğretmenlerin, öğrencilerin ev okuryazarlığı ortamları hakkında olası önyargılarını ve beklentilerini incelemelerini gerektirir. Bu çalışma ile farklı sosyoekonomik düzeydeki çocukların ev okuryazarlığı ortamları ebeveynlerin görüşleri doğrultusunda araştırılmıştır. Bu araştırmanın araştırma sorusu ise "Farklı sosyoekonomik (düşük-orta-üst) düzeyde yer alan ebeveynlerin ev okuryazarlığı yaşantıları nasıldır?” şeklindedir.

\section{Araştırmanın Modeli}

Yöntem

Bu araştırmada, nitel araştırma desenlerinden biri olan durum çalışması kullanılmıştır. Durum çalışmalarında var olan durumlar derin bir şekilde araştırılır ve bu durumları etkileyen ya da durumdan etkilenen faktörler üzerine odaklanılır (Cohen, Manion ve Morrison, 2005). Durum çalışmaları, bağlamsal ve diğer karmaşık koşulların geniş bir oranını kapsama arzusunun yanı sıra duruma/durumlara derinlemesine odaklanmanın, diğer karmaşık koşulların durumunu/ durumlarını anlamanın ayrılmaz bir parçası olduğunu varsayar (Yin, 2017). Bu çalışmada ebeveynlerin ev okuryazarlığı deneyimleri temel alınmış ve katılımcı ebeveynlerin deneyimlerini çocuklarına nasıl yansıttığı kişilerin gözünden nitel bir yaklaşımla incelenmiştir.

\section{Araştırma grubu}

Araştırmanın çalışma grubu, İstanbul ilinde ikamet etmekte olan ve çocukları okul öncesi dönemde olan 23 ebeveynden oluşmaktadır. Çalışma grubu belirlenirken amaçı örnekleme yöntemlerinden maksimum çeşitlilik örnekleme yöntemi (maximum variation sampling) kullanıımıştır. Ebeveynlerin sosyoekonomik düzeylerinin ev okuryazarlığı deneyimleri üzerinde etkili olabileceği gerekçesiyle bu araştırmada, farklı sosyoekonomik düzeyde (yüksek, orta, alt) ebeveynler çalışma grubuna dâhil edilmiştir. Çalışma grubu belirlenirken sosyoekonomik düzeye göre çeşitlilik sağlanmaya çalışılmıştır. Görüşme yapılan ebeveynlerin özellikleri Tablo 1'de verilmiştir.

Tablo 1.

Görüşme yapılan ebeveynlerin özellikleri

\begin{tabular}{lll}
\hline Özellik & Kategori & Sayı (N) \\
\hline \multirow{2}{*}{ Cinsiyet } & Anne & 22 \\
& Baba & 1 \\
\hline \multirow{2}{*}{ Sosyoekonomik düzey } & Alt sosyoekonomik düzey & 7 \\
& (E4/E9/E10/E11/E15/E17/E21) & \\
& Orta sosyoekonomik düzey & 8
\end{tabular}


(E2/E3/E5/E8/E16/E18/E23/E13)

Üst sosyoekonomik düzey 8

(E1/E6/E7/E12/E14/E19/E20/E22)

Tablo 1'de görüldüğü üzere, görüşme yapılan ebeveynlerin 22 'si anne, biri ise babadır. Ebeveynlerin yedisi alt sosyoekonomik düzeyde, sekizi orta sosyoekonomik düzeyde, sekizi ise üst sosyoekonomik düzeyde yer almaktadır. Sosyoekonomik düzey belirlenirken ailenin ortalama aylık geliri, anne ve babanın eğitim düzeyleri ve meslek grupları dikkate alınmıştır.

Tablo 2.

Görüşme yapılan ebeveynlere ilişkin sosyo-demografik veriler ( $N=23)$

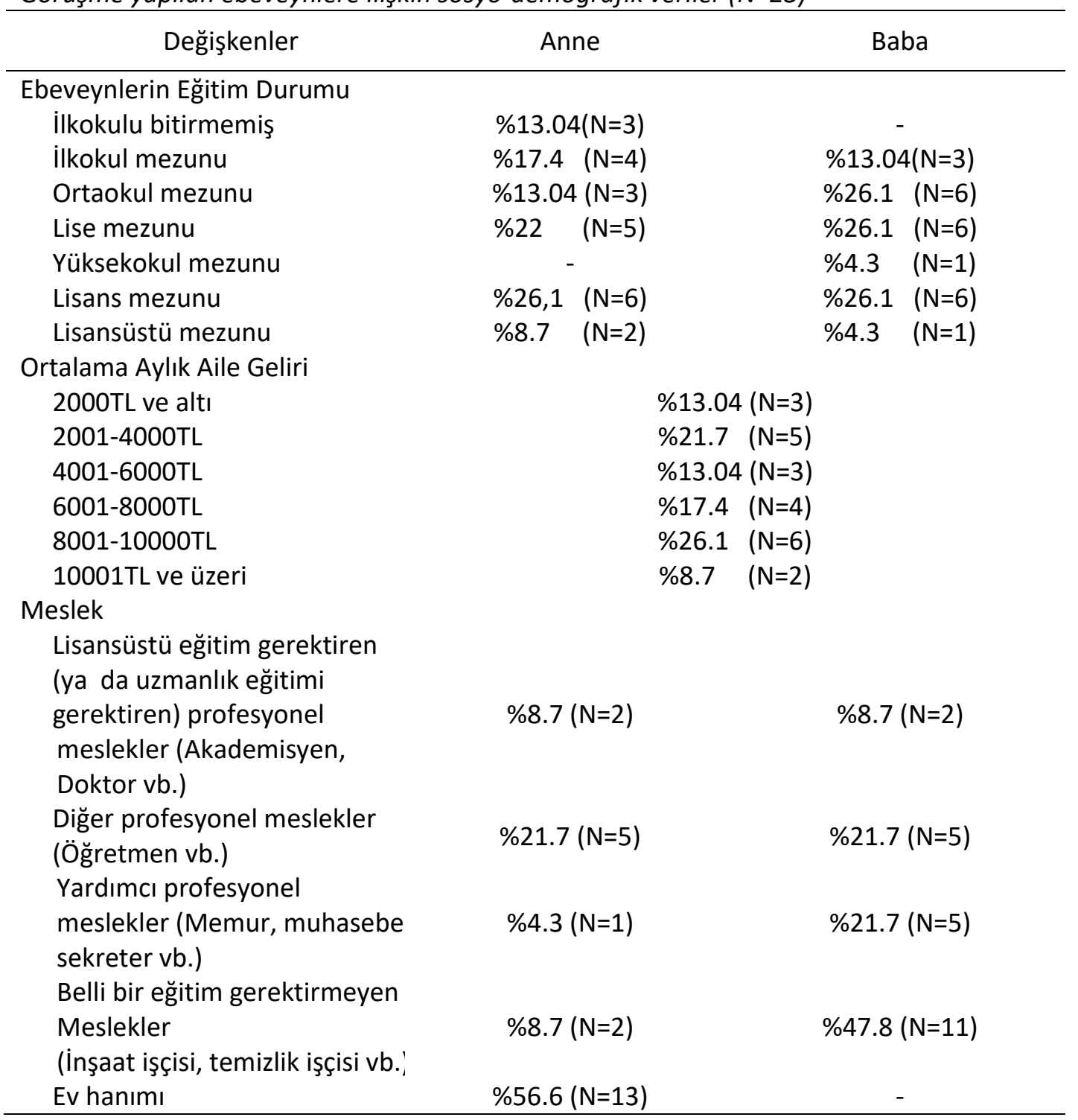

Tablo 2'de görüldüğü üzere görüşme yapılan ebeveynlerden annelerin \%13.04 (N=3)'ü ilkokulu bitirmemiş, \%17.4(N=4)'ü ise ilkokul mezunudur. Meslek gruplarına bakıldığında ise annelerin \%56.6 ( $\mathrm{N}=13)^{\prime}$ 'sı ev hanımı, \%8.7 ( $\left.\mathrm{N}=2\right)^{\prime}$ 'si ise belli bir eğitim gerektirmeyen meslekleri yapmaktadır. Babalarda ise en düşük eğitim durumu \%13.04 $(\mathrm{N}=3)$ ile ilkokul mezunu olanlardır. Meslek gruplarına bakıldığında babaların \%47.8 ( $N=11)^{\prime}$ inin belli bir eğitim gerektirmeyen meslekler yaptığı görülmektedir. Bu sosyo-demografik bilgilere sahip olan ebeveynler bu çalışmada eğitim durumu, aylık gelir ve meslek grubuna göre sınıflandırılarak alt ve orta sosyoekonomik düzeyde yer almaktadır. Özellikle lisans ve lisansüstü eğitim düzeyine sahip olan anneler (lisans=6; lisansüstü=2) 
ve babalar (lisans=6; lisansüstü=1), aylık gelir ve meslek gruplarına göre üst sosyoekonomik düzeyde yer almaktadır.

\section{Veri Toplama Araçları}

Araştırma verileri, yarı-yapılandırılmış görüşme formu ile toplanmıştır. Görüşme formu araştırmacılar tarafından geliştirilmiş, iki uzmandan uzman görüşü alınmıştır. Uzman görüşleri doğrultusunda forma son şekli verilmiştir. Görüşme formundaki sorular, ilgili alınyazındaki araştırmalar göz önünde bulundurularak hazırlanmıştır.

Görüşme formunun ön denemesi olarak, okul öncesi dönemde çocuğu olan bir ebeveyn ile görüşme yapılarak görüşsme formundaki soruların ebeveyn tarafından doğru anlaşılıp anlaşımadığı ve formun araştırmanın amacına uygun olup olmadığı test edilmiş; görüşme formundaki soruların anlaşılır olduğu belirlenmiştir.

\section{Verilerin Toplanması}

Görüşmeler 2017-2018 akademik yılı bahar döneminde; isstanbul'da ikamet eden ebeveynler ile belirlenen gün ve saatlerde uygun bir ortamda yüz yüze gerçekleştirilmiştir. Gönüllülük esasına dayalı olarak ebeveynlerle yapılan görüşmeler kendilerinin de izni alınarak ses kayıt cihazıyla kayıt altına alınmıştır. Araştırmanın veri toplama süreci üç hafta sürmüştür. Altı ebeveyn ile onların iş yerinde, iki tanesi ile ev ortamında, on beşi ile çocuklarının öğrenim gördüğü okul öncesi kurumunun bir odasında görüşmeler yapılmıştır. Bu görüşmeler toplamda 321 dakika 37 saniye sürmüştür. Daha sonra görüşme kayıtları bilgisayar ortamında yazılı hale getirilmiştir.

\section{Verilerin Analizi}

Araştırmadan elde edilen verilerin analizinde tümevarımsal analiz kullanılmıştır. Ebeveynlerle gerçekleştirilen görüşmeler ses kayıt cihazı ile kayıt altına alınmış ve transkript edilmiştir. Veriler analiz edilirken öncelikle kodlamalar yapılmıştır. Bu kodlar üzerinden alt temalar oluşturulmuştur. Ayrıca ebeveyn deneyimlerinin (kodların) her alt tema altında hangi sıklıkta tekrar ettiği hesaplanarak alt tema ve kodlamalar frekans ve yüzdelerle tablolaştırılmıştır. Örnek katılımcı söylemlerinin sunumunda katılımcılara ilişkin demografik bilgileri sunmak amacıyla kısaltmalardan (örneğin, E13/ÜSTSED/K) yararlanılmıştır. Kodun birinci kısmı (E13) "görüşmenin yapıldığı ebeveynin sıra numarasını"; kodun ikinci kısmı "görüşmenin yapıldığı ebeveynin sosyoekonomik düzeyini"; kodun üçüncü kısmı, katılımcının "cinsiyetini ( $K=$ Kadın; $E=$ Erkek)" göstermektedir. Ebeveynlerin görüşlerini açık ve tam bir şekilde yansıtabilmek amacıyla bulgular doğrudan alıntılarla desteklenmiştir. Görüşmelerden elde edilen veriler iki araştırmacı tarafından kodlanmış ve uyumlu kodlar oluşturmak için fikir birliğine varılmıştır. Veri analizinin daha net anlaşılması için örnek olan tema ve kodlama Tablo 3'de verilmiştir:

Tablo 3.

Nitel veri setini kodlama örneği

\begin{tabular}{llll}
\hline Tema & Alt Tema & Kodlar & Ebeveyn Söylemleri \\
\hline $\begin{array}{l}\text { Evde geçirilen } \\
\text { zaman }\end{array}$ & Okul odaklı & Ödev & $\begin{array}{l}\text { "Genelde ben sadece ödev } \\
\text { yaptırıorum. Öyle oyun oynamayı pek } \\
\text { seven bir anne değilim". }\end{array}$ \\
\hline $\begin{array}{l}\text { Kitap okuma/ } \\
\text { okumama } \\
\text { durumları }\end{array}$ & Hikâye kitabı okumama & Küçük yaş "...Yani daha henüz küçük olduğu için \\
Kütüphane & & $\begin{array}{l}\text { çok böyle etkinlik tarzı pek } \\
\text { yapmıgoruz..." }\end{array}$ \\
& $\begin{array}{l}\text { Kütüphane ziyareti } \\
\text { gerçekleştirmeme }\end{array}$ & Zamansızlık "Görse olur ama zamanımız yok ki..." \\
\hline
\end{tabular}




\section{Geçerlik ve Güvenirlik}

Araştırmanın iç geçerliği için bulgular doğrudan alıntılarla desteklenmiştir. Veri analizinin güvenirliğini belirlemek amacıyla iki hafta arayla gerçekleştirilen kodlamalarda görüş birliği ve görüş ayrılığı sayıları belirlenmiştir. Miles ve Huberman'ın (1994) “Güvenilirlik= ((Görüş Birliği):(Görüş Birliği + Görüş Ayrılığı))x 100" önerdiği formülle çalışmanın güvenilirlik değeri hesaplanmıştır. Çalışmada kodlayıcılar arasında, 5 kod üzerinde görüş ayrılığı olmuştur. Güvenilirlik için hesaplama şu şekilde yapılmıştır: [Güvenilirlik= ((95):(95+5))x100; Güvenilirlik= \%95]. Nitel çalışmalarda, kodlayılar arasındaki uyumun en az \%85 olması ile arzu edilen düzeyde bir güvenilirlik sağlanmış olmaktadır (Miles, Huberman ve Saldana, 2014, s.79). Çalışmada, farklı sosyoekonomik düzeyde yer alan ebeveynlerle yapılan görüşmelere ait bulgular ayrı ayrı raporlandırılmış ardından araştırmacılar tarafından karşılaştırmalı olarak irdelenmiştir. Söylemlerde söyleyenin duraklamalarına (ı gibi), ifade biçimlerine (ayvanımsı kitaplar) sadık kalınmıştır.

\section{Bulgular}

Araştırmanın bulguları, ebeveynlerin çocuklarıyla evde geçirdikleri zaman, kitap okuma durumları, yazma çalışmaları, kütüphane ziyaretleri, kitap seçimi ve bir kitaplığa sahip olma şeklinde aşă̆ıda verilmiştir.

\section{Ebeveynlerin Çocuklarıyla Evde Geçirdikleri Zamana ilişkin Bulgular}

Görüşme yapılan ebeveynlere "Çocuğunuzla evde geçirdiğiniz zamanlarda neler yapıyorsunuz?" sorusu yöneltilmiştir. Ebeveynlerin çocuklarıyla evde geçirdikleri zamanda ağırlıklı olarak yaptıkları aktiviteler sınıflandırıldığında aşağıdaki söylemler ve bu söylemlere ait sıklıklar Tablo 4'de sunulmuştur.

Tablo 4.

Ebeveynlerin çocuklarıyla evde geçirdikleri zaman

\begin{tabular}{|c|c|c|c|}
\hline Temalar & $f$ & $\%$ & Ebeveyn Söylemleri \\
\hline Birlikte Oyun/Etkinlik & 10 & 43 & $\begin{array}{l}\text { Vaktimizin \%60'ını \%70'ini ilgilenerek bir şekilde oynayarak } \\
\text { onunla oyun oynayarak geçirdik yani. (E7/ÜSTSED/E)/ Evde } \\
\text { oyunlarımız vardır genelde hep oynarız yani. Ailecek } \\
\text { babasıyla birlikte de oynarız yani. (E9/ALTSED/K)/ Valla her } \\
\text { şeyi yapıyoruz biz. Oyun, yemek bile yapıyoruz açıkçası. } \\
\text { Çünkü çok seviyor. Mutfağa girmeyi çok seviyor. } \\
\text { (E16/ORTASED/K)/ Oyuncaklarıyla oynuyoruz, oyun hamuru } \\
\text { yapıyoruz. (E18/ORTASED/K) }\end{array}$ \\
\hline Ödev Yaptırma & 6 & 26 & $\begin{array}{l}\text { Evde ödev veriyorlar, onu yapıyoruz. (E1/ÜSTSED/K)/ } \\
\text { Genelde tek uğraşımız var. Ödev veriliyor ödevlerle } \\
\text { uğraşıyoruz (E4/ALTSED/K)/ Evde geçirdiğimiz vakitlerde ona } \\
\text { ödev yaptırıyorum. (E6/ÜSTSED/K)/ Genelde ben sadece } \\
\text { ödev yaptırıyorum. Öyle oyun oynamayı pek seven bir anne } \\
\text { değilim. (E17/ALTSED/K) }\end{array}$ \\
\hline Tablet/Tv & 4 & 17 & $\begin{array}{l}\text { Bilgisayara bakıyor, film izliyor. (E12/ÜSTSED/K)/ O daha çok } \\
\text { telefonla ya da televizyon ekranında. (E15/ALTSED/K)/ } \\
\text { Tabletimiz çok fazla çok. (E23/ORTASED/K) }\end{array}$ \\
\hline Bireysel Oyun & 3 & 13 & $\begin{array}{l}\text { Genelde hep oyuncaklarla oynuyor yani, bebeklerle falan. } \\
\text { Böyle birlikte oynadığımız bir oyun yok. (E2/ORTASED/K)/ } \\
\text { Oyun hamuru var mesela oyun hamuruyla oynar, bisikleti var } \\
\text { bisiklet sürer. Oyuncaklarıla oynar. (E3/ORTASED/K)/ } \\
\text { Genelde kendi kendine oyun oynamayı seviyor. }\end{array}$ \\
\hline
\end{tabular}


(E11/ALTSED/K)

Toplam $23 \quad 100$

Not. Ondalık sayıların yuvarlanması nedeniyle yüzde hesaplamaları toplamda 100'den düşük çıkabilmektedir.

Tablo 4 incelendiğinde, ebeveynlerin çocuklarıyla evde geçirdikleri zaman, birlikte oyun/etkinlik, ödev yaptırma, tablet kullanımı ve bireysel oyun şeklinde sınıflandırılmıştır. Ebeveynlerin çocuklarıyla evde geçirdikleri zamanlarda çoğunlukla $(n=10)$ birlikte oyun oynadıkları ya da yemek yapma-mutfakta vakit geçirme gibi etkinliklere yöneldikleri görülmektedir. Evde çocuklarıyla ödev yapan ebeveynler ise $(n=6)$, okuldaki ödevleri yapmayı evde geçirilen zamanda en çok yapılan aktivite olarak değerlendirmişlerdir. Ebeveynlerden dört tanesi ise çocuklarıyla evde geçirdikleri zamanlarda ortak bir etkinlik yapmadıklarını bu zamanlarda çocuklarının genellikle tablet ile vakit geçirdiğini ifade etmişlerdir. Ebeveynlerden üç tanesi ise çocuklarıyla evde geçirdikleri zamanı düşündüklerinde, çocuklarının vakitlerinin çocuğunu bireysel (tek başına) oyun oynayarak geçirdiklerini belirtmişlerdir.

Sosyoekonomik düzeye göre incelendiğinde, evde geçirilen zamanın birlikte oyun oynama, ödev yapma/yaptırma, tablet/tv ile zaman geçirme ve çocuğun bireysel oyun oynaması durumlarının sosyoekonomik düzey açısından farklılaşmadığı söylenebilir. Üst-orta ve alt sosyoekonomik düzeyde yer alan aileler çocuklarıyla evde vakit geçirirken birbirleriyle benzer olarak çocuklarılya oyun oynadıklarını, ödev yaptıklarını, tablet/bilgisayar ile vakit geçirildiğini ve çocuğun bireysel oyun oynadığını ifade etmiştir.

\section{Ebeveynlerin Çocuklarına Kitap Okuma Deneyimleri/Deneyimsizliklerine Yönelik Bulgular}

Ebeveynlere, "Çocuğunuza kitap okuyor musunuz? Eğer cevabınız evet ise ne zamandan beri okuyorsunuz? "şeklinde sorulan soruya ebeveynlerin verdiği cevaplar evet/hayır olacak şekilde kodlanarak aşağıdaki tabloda verilmiştir.

Tablo 5.

Kitap okuma durumu

\begin{tabular}{|c|c|c|c|}
\hline Temalar & $f$ & $\%$ & Ebeveyn Söylemleri \\
\hline Evet & 17 & 74 & $\begin{array}{l}\text { Evet, okuyorum. O sorular soruyor ben ona sorular } \\
\text { soruyorum. (E1/ÜSTSED/K)/ O rahat uyusun diye okuyorum. } \\
\text { Yanında istiyor beni. Okuyunca iyi oluyor. (E2/ORTASED/K)/ } \\
\text { Yaklaşık beş aylıktan itibaren ona ben masal okuyorum } \\
\text { sürekli. (E7/ÜSTSED/E)/ Evet okuyorum, üç buçuk yaşından } \\
\text { beri. Biraz geç kaldık ama. (E14/ÜSTSED/K) }\end{array}$ \\
\hline Hayır & 6 & 26 & $\begin{array}{l}\text { Yok ben kitap okumuyorum. Şimdi zaten o büyük oğlum } \\
\text { okula gittiği için o okuyor, küçüğü dinliyor. (E4/ALTSED/K)/ } \\
\text { Kitap okumadım ama çok ninniler söylerdim ona. Ondan } \\
\text { sonra işte masallar anlatırdım onun üstünden } \\
\text { (E10/ALTSED/K) }\end{array}$ \\
\hline Toplam & 23 & 100 & \\
\hline
\end{tabular}

Tablo 5 incelendiğinde ebeveynlerin çoğunluğunun $(n=17)$ çocuklarına kitap okuduğu söylenebilir. Kitap okuyan ebeveynlerin ne sıklıkla okuduğu incelendiğinde ise 17 ebeveynden dört tanesinin bebekliğinden beri çocuğuna kitap okuduğu görülmüştür. Bu ebeveynler küçük yaşlardan itibaren çocuklarına kitap okuduklarını ifade etmişlerdir.

"...Yaklaşık 6 aylıktan beş aylıktan itibaren ona ben masal okuyorum sürekli. Dinliyormuş gibi görünüyordu ilk başlarda. Acaba dinliyor mu falan derken sonradan bir yaşını geçtikten sonra konuşmaya başlayınca baktık ki şey mesela hikâye kitabını okuyorum yarım kaldığım yerde o tamamlıyor. Ben mesela işte okurken boğazım düğümlendi mesela ben unuttum zannedip o 
tamamlayınca biz olayın farkına vardık. Devam ediyor üstünden devam etmeye başlayınca ben tabi öyle olunca bir sürü hikâye, hikâyeye daha da önem verdik... (E7/ÜSTSED/E)"

Küçük yaştan itibaren çocuklarına kitap okuyan ebeveynlerin, hikâye tamamlama gibi etkileşimli okuma çalışmalarına yer verdiği ifadelerden hareketle söylenebilir. Buna karşın, kitap okumaya okul ile birlikte başlayan ya da sadece akşamları çocukları uyumadan önce kitap okuyan ebeveynler de mevcuttur.

“...Okuyorum. Okula başladıktan sonra okumaya başladım. Daha öncesinde okumuyordum... (E3/ORTASED/K)"

"...Mesela her gece yatarken hikâye okuyoruz...(E12/ÜSTSED/K)"

"...Gece bir de yatmadan evvel okuyorum. Bazen yanımda olmuyor internetten okuyorum. Genelde masal okuyorum... (E19/ÜSTSED/K)"

Ebeveynlerden sekiz tanesi kitap okuduktan sonra çocuklarına sorular sorduklarını, hikâye tamamlama gibi etkinlikler yaptırdıklarını ifade etmişlerdir.

"...O sorular soruyor ben ona sorular soruyorum... (E1/ÜSTSED/K)"

"...Okuduğumuz hikâye ile ilgili konuşuyoruz. Yorumlar yapıyoruz... (E6/ÜSTSED/K)"

"...Yarım kaldığım yerden o tamamlıyor... (E7/ÜSTSED/E)"

E1, E6 ve E7 sosyoekonomik düzey olarak üstte olan ebeveynlerdir. Yukarıdaki ifadelerden sosyoekonomik düzeyi yüksek olan ebeveynlerin çocuklarına kitap okuma durumları ve okunan kitapla ilgili hikâyeyi devam ettirme, soru sorma, özetleme gibi çalışmaları yaptıkları görülmektedir. Buna göre özellikle sosyoekonomik düzey arttıkça, bu gibi etkinliklerin fazlalaştığı söylenebilir.

\section{Kitap okumayan ebeveynlerin gerekçeleri}

Tablo 5 incelendiğinde ebeveynlerin altı tanesinin çocuklarına kitap okumadığı söylenebilir. Kitap okumayan ebeveynler bu durumun gerekçesi olarak, abla/abinin küçük çocuğa kitap okuması, kitap okumayı sevmediğinden çocuğuna da okumaması, akıllarından anlatmanın yeterli olması, çocuğun yaşının küçük olması gibi sebepler sunmuşlardır.

“...Böyle hani kitaptan hikâye okuyalım değil de biz daha çok hani hikâye istiyor. Biz kendimiz aklımızdan anlatıyoruz ona... (ES/ALTSED/K)"

“...Yani daha henüz küçük olduğu için çok böyle etkinlik tarzı pek yapmıyoruz... (E9/ALTSED/K)"

"...Ben okumayı çok sevmiyorum da eşim bazen onlara yatarken okuyor... (E11/ALTSED/K)"

"....Ben değil de onun ablası var. O okuyor. Benle pek işi olmuyor... (E21/ALTSED/K)"

Kitap okumayan ebeveynlerin bu sorumluluğu abla/abi ya da eşe yüklediği söylenebilir. Bu sebeple okumanın niteliği kitabı okuyup geçme şeklinde olmaktadır. Etkileşimli kitap okuma ve çocuğa katkı sağlamak için okuma bu durumlarda mümkün olmamaktadır. Kitap okumak ve etkileşimli kitap okuma etkinlikleri gerçekleştirmek için çocuğun yaşının küçük olarak görülmesi ise ev okuryazarlığının olmadığını, kitap okumanın ve bunu etkileşimli olarak gerçekleştirmenin sadece ödev/görev olarak görüldüğü söylenebilir. Etkileşimli kitap okumadıkları için sunulan gerekçeler alt sosyoekonomik düzeyde fazlalaşmaktadır.

\section{Yazmaya Hazırlık Çalışmalarına Yönelik Bulgular}

Görüşme yapılan ebeveynlere "Çocuğunuzla yazı yazmaya hazırlık sürecinde ne gibi etkinlikler yapıyorsunuz?" sorusu yöneltilmiştir. Soru sorulurken ebeveynlere yazı yazmaya hazırlık süreci ile kast edilen anlatılmıştır. Bunun sonucunda ebeveynlerin çoğunluğunun $(n=13)$, çocukları ile birlikte yazmaya hazırlık çalışmalarına okul öncesi kurumundan verilen ödevler aracılığıyla başladığı söylenebilir. Ebeveynlerin bir kısmı ( $n=7)$ çocuklarına okul öncesi dönemden önce de yazmaya hazırlık çalışmaları yaptırmıştır. Bu çalışmalar oyun hamuru ile el-kol kaslarını geliştirici çalışmalar, boyama çalışması, kalem tutma, kesme şeklindedir. Yazma çalışmaları yaptıran bu ailelerin daha çok üst sosyoekonomik düzeyde yer aldığı görülmektedir. Buna karşın ebeveynlerin üç tanesi çocuğuyla hiçbir yazmaya hazırlık çalışması yapmadığını ifade etmiştir. Bu ebeveynlerin tamamı alt sosyoekonomik düzeyde yer alan ebeveynlerdir. Ebeveynlerin çocuklarıyla yaptığı yazı çalışmalarına ait söylemler ve bu söylemlere ait sıklıklar Tablo 6'da sunulmuştur. 
Tablo 6.

Ebeveynlerin çocuklarıyla yaptığı yazmaya hazırlık çalışmaları

\begin{tabular}{|c|c|c|c|}
\hline Temalar & $f$ & $\%$ & Ebeveyn Söylemleri \\
\hline $\begin{array}{l}\text { Okulla paralel } \\
\text { yürütülen yazmaya } \\
\text { hazırlık çalışmaları }\end{array}$ & 13 & 57 & $\begin{array}{l}\text { Okuldan gelen çizgi çalışmalarını yapıyoruz. Pedagoglar bile } \\
\text { çocuğu sıkmayın diyor. Ondan çok da şey yapmıyoruz } \\
\text { (E1/ÜSTSED/K)/ Ödevlerini yaparken yanında duruyorum, } \\
\text { sayıları yazıyor, boyama oluyor. (E2/ORTASED/K)/ Kalem } \\
\text { tutmayı göstermedim, resim çizmeye de çok meraklı değildi } \\
\text { ama okulla beraber başladık. (E6/ÜSTSED/K)/ Öğretmen ödev } \\
\text { verdiği zaman defterinde ismi yazıyor ona bakarak yazmaya } \\
\text { başlamıştı. Ondan sonra biz de yardımcı olduk. } \\
\text { (E22/ÜSTSED/K)/ Yok hiç bir şey yaptırmıyordum. Kalem } \\
\text { tutmasını bilmiyordu eline alıp. Okulun çok faydası oldu çok } \\
\text { (E23/ORTASED/K). }\end{array}$ \\
\hline
\end{tabular}

Çok önceden beri, kasları geliştiğinden beri yazmaya hazırlık yapıyoruz, oyun hamurları çok oynadığı için yani bir buçuk yaşından beri yapılıyor yani onlar. Kalem tutuyor, çiziyor, karalıyor. Mesela her akşam mutlaka bir yazı çalışması

Küçüklükten beri yapılan yazmaya hazırlık çalışmaları

Okula atfetme/yaşın küçük olduğunu düşünme yapıyoruz. (E7/ÜSTSED/E)/ Kesme, kalem tutma, boyama gibi çalışmalar yapıyoruz eskiden beri (E13/ORTASED/K)/ Hamurlarla önceden resimler yapıyorduk işte, ne olabilir, atıyorum inek olur ya da bir tavşan olur gibi. Ama şimdi harfleri yapıyoruz. Sayıları yapıyoruz. (E20/ÜSTSED/K).

Çocuklar genelde sıkılıyorlar. Öğretmeni de okuldaki gibi evde ortam sağlayın ve yardım edin. Ama tabi biz de öyle ortam yok. O yüzden yazma yaptırmıyorum. Okulda yapsın. (E4/ALTSED/K)/ Ben kafası karışmasın diye hiç yazmaya hazırlık yaptırmadım. Yaşı küçük. (E10/ALTSED/K)/ Daha dedim ya çok küçük diye şey yapmak istemiyorum. Üzerine de fazla gitmek istemiyorum. Çünkü daha çok erken. İlkokula var daha (E17/ALTSED/K).

$\begin{array}{lll}\text { Toplam } & 23 \quad 100\end{array}$

Tablo 6'ya göre ebeveynlerin çoğunluğunun $(n=13)$ yazmaya hazırlık çalışmalarına okul ile birlikte başladıkları, bu çalışmaların ödev ağırlıklı olduğu söylenebilir. Bu ödevler kapsamında aileler çocuklarına çizgi çalışmaları, boyamalar yaptırmaktadır. Bununla birlikte çocuğunun küçük yaşından itibaren yazma çalışmaları yapan $(n=7)$ ebeveynler de mevcuttur. Bu çalışmalar oyun hamuru ile elkol kaslarını geliştirici çalışmalar, boyama çalışması, kalem tutma, kesmeye yöneliktir. Bu ebeveynler üst ve orta sosyoekonomik düzeyde yer almaktadır. Çocuğu ile yazma çalışması yapmayan ebeveynler $(n=3)$ alt sosyoekonomik düzeyde yer almaktadır ve bu durumu çocuklarının yaşlarının küçük olmasına ya da bunu okulun yapması gerektiğine bağlamışlardır.

\section{Çocukların Kütüphane Görme Durumlarına İlişkin Bulgular}

Görüşme yapılan ebeveynlere "Çocuğunuz daha önce kütüphane gördü mü? Gördüyse oraya nasıl gitti (sizinle mi, okul gezisi mi?) ve bunun bir rutini var mı? şeklinde bir soru yöneltilmiştir. Ebeveynlerin bu soruya ilişkin verdiği cevap çocuğun kütüphane görüp görmemesi durumundan hareketle "evet", "hayır" olarak Tablo 7'de verilmiştir. 
Tablo 7.

Çocukların kütüphane görme durumları

\begin{tabular}{|c|c|c|c|}
\hline Temalar & $f$ & $\%$ & Ebeveyn Söylemleri \\
\hline Evet & 4 & 17 & $\begin{array}{l}\text { Hı hı. Götürdüler okul gezisiyle. (E4/ALTSED/K)/ Gördü. } \\
\text { Okuldaki faaliyetlerinde gittiler. (E6/ÜSTSED/K)/ Ablasını } \\
\text { havuza götürdügümde onu bırakacak yerim yok diye } \\
\text { kütüphaneye bırakıyorduk. O da orda ödevini yapıyordu. } \\
\text { Oraya da üye de olmuştuk hatta o gün birkaç tane kitap } \\
\text { getirmiştik eve. Biliyor kütüphanenin ne olduğunu, orda } \\
\text { neler yapıldığını biliyor. (E11/ALTSED/K)/ Bundan bir yıl önce } \\
\text { falan kardeşim götürmüştü. Hatta anne demişti kütüphane } \\
\text { çok güzel demişti. bi o zaman gitti ben götürmedim yani. } \\
\text { Okuldan fırsat bulamıyoruz ki hep okuldayız. } \\
\text { (E18/ORTASED/K). }\end{array}$ \\
\hline Hayır & 19 & 83 & $\begin{array}{l}\text { Hiç görmedi. Görse bayılır (gülüyor). (E8/ORTASED/K)/ Bu } \\
\text { havuzun kütüphanesi var herhalde. Oraya da gitmedik. } \\
\text { Çünkü küçük olduğu için oraya da götürmedim. } \\
\text { (E12/ÜSTSED/K)/ Yok görmedi. Ama çok istiyorum. Kitap } \\
\text { fuarına götürmek çok istiyorum görsün ama şöyle bir iki yıl } \\
\text { sonra filan. Aklı başındayken, anlayabileceği yaşta olsun diye. } \\
\text { (E17/ALTSED/K) }\end{array}$ \\
\hline Toplam & 23 & 100 & \\
\hline
\end{tabular}

Tablo 7'ye göre görüşme yapılan ebeveynlerin yalnızca dört tanesinin çocuğu kütüphane görmüştür. Bu çocuklardan bazılarının $(n=2)$ kütüphane görmeleri okul gezisi şeklinde olmuştur. $B u$ çocukların ailelerinden biri alt diğeri ise üst sosyoekonomik düzeyde yer almaktadır. Bilinçli ve düzenli bir kütüphane ziyareti sosyoekonomik düzey fark etmeksizin hiçbir aile tarafından gerçekleştirilmemiştir. Ebeveynlerden biri düzenli görmeme durumunu okula atfetmiştir (Bkz. Tablo 4-E18/ORTASED/K).

\section{Ebeveynlerin Çocuklarına Kitap Almaları ve Kitap Seçimlerine iliş̧in Bulgular}

Görüşme yapılan ebeveynlere "Çocuğunuza kitap alıyor musunuz? Kitap seçerken nelere dikkat ediyorsunuz? şeklinde bir soru yöneltilmiştir. Ebeveynlerin bu soruya ilişkin verdiği cevaplar Tablo 8'de yer almaktadır.

Tablo 8.

Kitap seçimi

\begin{tabular}{|c|c|c|c|}
\hline Kategoriler & $f$ & $\%$ & Ebeveyn Söylemleri \\
\hline Kendi Seçimi & 10 & 44 & $\begin{array}{l}\text { Kendi seçiyor (E6/ÜSTSED/K)/ Yani ben aslında ona } \\
\text { seçtirmeye çalışıyorum. Sevdiği kitapları alıyor } \\
\text { (E13/ORTASED/K)/ Kendi seçiyor. Hep ona bırakıyorum } \\
\text { (E14/ÜSTSED/K)/ Hayvan figürlü olanları kendi seçiyor }\end{array}$ \\
\hline
\end{tabular}

Renkli, canlı, yaşına uygun kitapları bulup içlerinden ona seçtiriyorum (E1/ÜSTSED/K)/Kitaplarını genelde kendi seçiyor ama ben yönlendiriyorum mesela bak bunlar sana uygun

Yönlendirme $\quad 6 \quad 26$ bunların içinden seçebilirsin diyorum (E7/ÜSTSED/E)/ Resimlerine bakıyorum. Pis hayvan resimlerini eve sokmak istemiyorum. Sonra ona gösteriyorum. Birlikte seçiyoruz (E21/ALTSED/K) 
Ben kendim alıyorum (E8/ORTASED/K)/ Ben seçiyorum ona bıraksam hep stickerlı olanları alır (E11/ALTSED/K)/ Ebeveyn Seçimi $\quad 6 \quad 26 \quad$ Anlayabileceğini düşündüğüm cinsel içerikli olmayan kitapları ben alıyorum (E19/ÜSTSED/K)/ Çocuğun psikolojisine göre ben seçiyorum (E22/ÜSTSED/K)

Kitap Almama $\quad 1 \quad 4 \quad$ Sağdan soldan arkadaşlar ne getirirse okuyoruz. Ben kitap almıyorum (E17/ALTSED/K)

Toplam $23 \quad 100$

Tablo 8'e göre ebeveynlerin büyük çoğunluğu $(n=10)$ kitap seçimini çocuklarına bırakmaktadır. Altı tanesi ise kendilerinin çocukları yönlendirdiklerini nihai kararı çocuğun verdiğini belirtmiştir. Yönlendirme sürecinde, kitabın resimleri, renkli olması, yazıları, yaşına uygunluğu gibi kriterleri göz önünde bulundurduklarını ifade etmişlerdir. Altı ebeveyn ise kitap seçerken bu seçimi çocuklarına bırakmadıkları tamamen kendileri seçip aldığını ifade etmişlerdir. Bir ebeveyn ise çocuğuna kitap almadığını, çevreden gelen tanıdıkların verdiği kitapları okuduğunu ifade etmiştir. Bu ebeveyn alt sosyoekonomik düzeyde yer almaktadır.

\section{Evde Kitaplık Olup Olmaması Durumu}

Görüşme yapılan ebeveynlere "Evde çocuğunuza ait bir kitaplık bulunuyor mu?" şeklinde bir soru yöneltilmiştir. Ebeveynlerin bu soruya ilişkin verdiği cevap çocuğun evde kendisine ait bir kitaplığın bulunup bulunmamasına göre "var", "yok", "raf/sepet" olarak Tablo 9'da verilmiştir.

Tablo 9.

Çocukların kitaplığa sahip olup olmama durumları

\begin{tabular}{|c|c|c|c|}
\hline Temalar & $f$ & $\%$ & Ebeveyn Söylemleri \\
\hline Var & 7 & 30 & $\begin{array}{l}\text { Evet kitaplığı } \\
\text { (E6/ÜSTSED/K)/ } \\
\text { Kendi }\end{array}$ \\
\hline Yok & 10 & 44 & $\begin{array}{l}\text { Yok kitapları öyle abisiyle ortak. (E4/ALTSED/K)/ Yok } \\
\text { kitaplığı.. (E5/ORTASED/K)/ Yok evdeki dolaba koyuyor } \\
\text { (E10/ALTSED/K)/ Ablasının çalışma masasının köşesine } \\
\text { koyuyor (E11/ALTSED/K)/ Yok. Küçük bir çekmeceye koyuyor } \\
\text { (E21/ALTSED/K). }\end{array}$ \\
\hline Raf/sepet & 6 & 26 & $\begin{array}{l}\text { Kitap kutusu yaptık biz. Kutuda saklıyor (E8/ORTASED/K)/ } \\
\text { Duvarda rafı var (E13/ORTASED/K)/ Sepet yaptık sepetine } \\
\text { koyuyor. (E14/ÜSTSED/K) }\end{array}$ \\
\hline Toplam & 23 & 100 & \\
\hline
\end{tabular}

Çocukların evde kendilerine ait kitaplığının olup olmama durumları Tablo 9'a göre incelendiğinde çoğunluğunun ( $n=10)$ kitaplığının olmadığı görülmektedir. Bu aileler sosyoekonomik açıdan incelendiğinde çoğunluğu alt diğerleri ise orta sosyoekonomik düzeyde yer almaktadır. Üst sosyoekonomik düzeyde yer alan ebeveynlerin altı tanesinin kitaplığı olduğu, iki tanesinin ise sepet/raf gibi alternatif çözümler üretmeye çalıştığı söylenebilir.

Çalışma sonucunda, görüşme yapılan ebeveynlerin ev okuryazarlığı deneyimlerinin sınırlı olduğu söylenebilir. Çocuklarına kitap okuyan ve bunu etkileşimli hale getiren ebeveynlerin üst sosyoekonomik düzeyde yer aldığı, sosyoekonomik düzey azaldıkça bu deneyimlerin azaldığı 
görülmektedir. Çocuklarını kütüphaneye götürme ve bunu düzenli olarak bilinçli bir şekilde yapma sosyoekonomik düzey fark etmeksizin hiçbir ebeveyn tarafından gerçekleştirilmemektedir. Bu çalışmanın sonucunda ebeveynlerin ev okuryazarlığı konusundaki deneyimlerin üst sosyoekonomik düzeyde daha fazla olsa da yeterli olmadığı sonucuna ulaşılabilir.

\section{Tartışma ve Sonuç}

Araştırmaya katılan ebeveynlerin çocuklarıyla birlikte evde geçirdikleri zaman değerlendirildiğinde genellikle oyun oynama, ödev yaptırma, tablet ya da televizyon izleme şeklinde vakit geçirdikleri görülmektedir. Çalışmalarda erken okuryazarlık ile ilgili oyunların çocukların fonolojik farkındalık, yazı farkındalığı, sözcük bilgisi gibi erken okuryazarlık becerilerine olumlu etkileri olduğu görülmüştür (Early, Maxwell, Burchinal, Alva, Bender, Bryant, Cai ve Zill, 2007; Onchwari ve Kenngwe, 2010). Türkiye'de yapılan benzer çalışmalarda (Uluğ, 2018; Akkuş, Yılmazer, Şahinöz ve Sucaklı, 2015; Öztürk ve Karayağız, 2007) televizyon izleyen çocukların çoğunluk olduğu görülmektedir. Uluğ (2018)'in çalışmasında televizyon/video izlerken çocukların ebeveynleri ile bir etkileşimlerinin olmadığı görülmüştür. Etkileşimli olarak televizyon/video izlemenin okuryazarlık becerilerini geliştirdiği (Moses ve Duke, 2008) bulunsa da bu çalışmada ebeveynlerin çocukları ile evde geçirdikleri zamanın niteliklerinin sınırlı olduğu görülmektedir. Uluğ (2018)'a göre önemli olan çocukla tüm gün beraber olmak değil, kaliteli vakit geçirmektir. Bu araştırmada ebeveynlerin çocuklarıyla evde kaliteli zaman geçirme konusunda sosyoekonomik düzey fark etmeksizin eksik oldukları söylenebilir.

Araştırmaya katılan 23 ebeveynin \%74'ünün çocuğuna kitap okuduğu, \%6'sının ise çocuğuna kitap okumadığı görülmektedir. Kitap okumalarının ise etkileşimli bir şekilde olması sürecinde eksiklikler görülmektedir. Benzer şekilde Uluğ (2018) çalışmasına katılan ebeveynlerin \%37,3'ünün çocuklarına kitap okumadıklarını, \%44.7'sinin ise çocuklarına 12 aylık ve üstü iken kitap okumaya başladıklarını belirtmişilerdir. Bu araştırmada da kitap okuyan ebeveynlerin yalnızca dört tanesi küçük yaşlardan itibaren çocuğuna kitap okumaktadır ve bu ebeveynler üst sosyoekonomik düzeyde yer almaktadır. Alan yazında ebeveynlerin çocuklarına kitap okuduğunu ve okunan bu kitapların onların ilkokuldaki sözel dil becerileri üzerinde olumlu etkisini açıklayan birçok çalışma bulunmaktadır (Audet, Evans, Williamson ve Reynolds, 2008; Deckner, Adamson ve Bakeman, 2006; Senechal, LeFevre, Thomas ve Daley, 1998). Daha iyi bir sözel dil becerisine sahip çocukların okuma yazmayı öğrenme sürecinde sözcükleri daha iyi tanıdıkları ve okuduklarını daha iyi anladıklarını ortaya konmuştur (Senechal ve LeFevre, 2002). Bebeklik döneminde okunan kitapların çocuğun dil ve sosyal gelişimi için gerekli olduğu bilinmektedir (Jellinek, Patel ve Froehle, 2002). Küntay (2013) daha hamilelik döneminde hazırlanan odalarda çocuklar için kitap okuma alanı oluşturmak gerektiğini ifade etmektedir. Kitap okuyan ebeveynlerin yalnızca sekiz tanesi kitap okuma etkinliğini anlamlı hale getirerek etkileşimli kitap okuma etkinliklerine yer vermektedir. Alan yazındaki çalışmalara bakıldığında paylaşımlı kitap okuma ve hikâye tamamlama gibi okuma yazma etkinlikleri ebeveynlerin çocuklarıyla birlikte yaptığı etkinliklerdir (Cunningham ve Zibulsky, 2011). Ayrıca bu etkinliklerin çocukların hikâyenin yapısını kavramalarına yardımcı olduğunu gösteren çalışmalar bulunmaktadır (Akyüz ve Doğan, 2017; Cunningham ve Zibulsky, 2011). Bu çalışmada ebeveynlerin ifade ettiği gibi çocukların kitap okuma esnasında bazı bölümleri kendilerinin tamamlaması gibi diyaloğa dayalı etkinliklerin çocukların sözel dil becerileri üzerinde büyük bir etkiye sahip olduğu alan yazındaki çalışmalarca desteklenmektedir (Sim, Berthelsen, Walker, Nicholson ve Fielding-Barnsley, 2014). Bu nedenle ev okuryazarlığı kapsamında ailelerin çocuklarıyla kitap okumasının onların okuma yazma sürecinde daha iyi performans göstermesine yardımcı olacağı söylenebilir.

Bu araştırmada kitap okumayan ebeveynler bu durumun gerekçesi olarak, abla/abinin küçük çocuğa kitap okuduğu bu yüzden kendilerinin okumaması, kitap okumayı sevmediğinden çocuğuna da okumaması, akıllarından anlatmanın yeterli olması, çocuğun yaşının küçük olması, bu gibi etkinliklerin okulda yapılması gibi ifadelerde bulunmuşlardır. Ailelerin çocuklarıyla paylaşımlı kitap okumaya yatkın olmadıkları ve bu sorumluluğu abi ve abla gibi çocukların birinci derece yakınlarına yükledikleri görülmektedir. Benzer şekilde Uluğ (2018) ev okuryazarlığı etkinliklerine yer vermeyen ailelerin gerekçe olarak yeterli zamanlarının olmaması, çocuklarının küçük olmasını sunduklarını bulmuştur. 
Alan yazında ebeveynlerin okuryazarlık inançları ve görüşlerinin çocukların erken okuryazarlık becerileri ve ev okuryazarlık ortamının kalitesi ile ilişkili olduğu görülmektedir (Weigel, Martin ve Bennet, 2006; Bingham, 2007; Norman, 2007; Curenton ve Justice, 2008). Bu etkinliklere yer vermeyen ebeveynlerin çocuğun yaşını küçük görmesi ve okula atfetme durumları ebeveynlerin erken okuryazarlık ile ilgili yeterli bilgisinin olmadığının göstergesi olarak kabul edilebilir.

Bu araştırmada ebeveynlerin \%57'sinin çocuklarının okula başlamaları ile birlikte yazmaya hazırlık çalışmaları yaptığı, \%30'unun küçük yaştan itibaren yazmaya hazırlık çalışmaları yaptığını, \%13'ünün ise bu çalışmaları yapmadığı sonucuna ulaşılmıştır. Yazmaya hazırlık çalışmaları yapan ebeveynlerin çocukları ile birlikte yazmaya hazırık çalışmalarına yönelik oyun hamuru ile el-kol kaslarını geliştirici çalışmalar, boyama çalışması, kalem tutma, çizgi çalışması ve kesme gibi etkinlikler yaptıkları görülmüştür. Alan yazındaki çalışmalarda ebeveynlerin genellikle harflerin ve seslerin arasındaki ilişkiye yönelik çalışmalar yaptıklarını ve bunun çocukların ilkokulda okuma yazmaları üzerinde olumlu etkileri olduğunu göstermektedir (Akyüz, 2016; Martini ve Senechal, 2012). Puranik, Phillips, Lonigan ve Gibson (2018) ebeveynlerin çocukları ile yaptıkları yazma çalışmaları ve ev okuryazarlık etkinliklerinin çocukların erken yazma becerilerine katkılarının olduğunu bulmuşlardır. Ev okuryazarlık etkinliklerinin harf yazımı, imla ve kendiliğinden gelişen yazma becerileri ile ilişkili olduğu görülmüştür. Yazmaya hazırlık çalışmalarına ev ortamında yer verilmesinin çocukların erken okuryazarlık becerileri üzerinde olumlu etkisi olabileceği söylenebilir.

Bu araştırmada ebeveynlerin \%83'ü çocuklarının kütüphane görmediğini, \%17'si ise gördüğünü ifade etmiştir. Çocuğu kütüphane ile tanışan ebeveynler ise çocuklarının ya okul gezisi ya da başka bir etkinlik ile kütüphaneye gittiklerini ve çocuklarının kütüphaneyi çok sevdiklerini ifade etmişlerdir. Kütüphane ortamını görmeyen çocukların ebeveynleri gerekçe olarak yaş küçüklüğünü sunmuştur. Benzer şekilde Uluğ (2018) yaptığı çalışmada araştırmaya katılan çocukların sadece iki tanesinin kütüphaneye gittiğini tespit etmiştir. Altun ve Tantekin Erden (2015), ölçek kullanarak yaptığı çalışmada, kitap okuma-kütüphane ve tiyatro" ziyaret etmeye yönelik alt boyutun en düşük madde ortalamasına sahip olduğu sonucuna varmışlardır. Çocukların erken yaşta kitaplarla tanıştırılmasının erken okuryazarlık üzerindeki etkileri düşünüldüğünde erken yaşta çocukların kütüphane ortamına dâhil olmasının olumlu etkilerinin olabileceği söylenebilir.

Bu çalışmaya katılan ebeveynlerin çocuklarının \%30'unun bir kitaplığı olduğu, \%44'ünün bir kitaplığı olmadığı, \%26'sının ise kitaplı̆̆ı olmasa da bir sepet ya da raf kullandıkları sonucuna ulaşıımıştır. Benzer şekilde Uluğ (2018), araştırmalarına katılan 12-36 aylık çocukların çoğunluğunun evlerinde 1-15 arası kitap bulunduğu, çocuk kitabı okuma alanı bulunmadığı ve kitaplara kolayca erişemedikleri sonucuna ulaşmıştır. Baydar, Küntay, Yağmurlu, Aydemir, Çankaya, Gökşen ve Cemalcılar (2014), Türkiye'de ekonomik ve sosyal bağlamda risk altında olan üç yaş aralığındaki çocukların ev ortamında çocuk kitapları ve okuma materyallerinin bulunmasının onların kelime dağarcığının gelişimini desteklediği sonucuna ulaşmışlardır. Çocuklarının kitaplara kolayca erişebilmesi ve aitlik hissedebilmeleri için önemli görülen kitaplığa sahip olma durumunun erken okuryazarlık becerilerini olumlu etkileyebileceği söylenebilir.

Çalışmaya katılan ebeveynlerin \%96'sı çocuklarına kitap aldığını, \%4'ü ise çevreden kitap verildiğini bu sebeple almaya gerek görmediğini ifade etmiştir. Dulay, Cheung ve McBride (2018) çalışmalarında, çocukların evlerindeki kitap sayısının ve bu kitaplara ulaşabilme durumlarının çocukların erken okuryazarlık becerileri ile ilişkili olduğunu gözlemişlerdir. Benzer şekilde Altun, Tantekin Erden ve Snow (2016) çalışmalarında evde bulunan çocuk kitabı sayısının yazı farkındalık becerisi ile ilişkili olduğu sonucuna varmıştır. Ebeveynlerin \%44'ü kitapları çocuğunun kendisinin seçtiğini, \%26'sı yönlendirmede bulunduğunu ve ortak seçtiklerini, \%26'sı ise kendilerinin seçtiğini belirtmişlerdir.

$\mathrm{Bu}$ araştırma sonucunda ebeveynlerin sosyoekonomik düzeyleri ile ev okuryazarlığı durumlarının ilişkili olabileceği görülmüştür. Evdeki okuryazarlık çevresi, ebeveyn eğitimi (özellikle anne eğitim düzeyi), sosyoekonomik düzey, çocuktan beklentiler, ebeveyne yönelik öğretim çalışmaları ve ebeveynlerin eğitime yönelik bakış açıları çocukların okuryazarlık gelişimlerinin nasıl olabileceği hakkında fikir veren önemli göstergeler olarak kabul edilmektedir. Bu çalışmadaki üst sosyoekonomik düzeyde yer alan ebeveynler erken okuryazarlık ile ilgili bazı bilgilere sahip ve bunun 
çocuğu için önemli olduğunun farkında olan ebeveynlerdir. Bu nedenle ev okuryazarlığı deneyimleri daha fazladır. Ergül, Sarıca, Akoğlu ve Karaman (2017) üç farklı sosyoekonomik seviyeden, okul öncesi eğitim kurumuna devam eden 341 çocuğun ebeveynleri ile yaptıkları çalışmada ev okuryazarlık ortamının sosyoekonomik durum ile ilişkisini incelemeyi amaçlamışlardır. Çalışma sonucunda yüksek sosyoekonomik seviyedeki ailelerin ev okuryazarlık ortam puanlarının orta ve düşük sosyoekonomik seviyedeki ailelere göre daha yüksek olduğu görülmüştür. Ancak sonuçlara göre her üç sosyoekonomik seviyedeki ailenin orta düzey ev okuryazarlık ortam puanına sahip olduğu bulunmuştur. Bu araştırmada da benzer şekilde üst sosyoekonomik düzeyde yer alan ebeveynlerin ev okuryazarlığı daha çok olsa da sosyoekonomik düzeylerin hepsi için yeterli değildir. Özbek Ayaz (2015) çalışmasında, okul öncesi eğitim kurumuna giden 5-6 yaş grubu 250 çocuğun ebeveynlerinin sosyoekonomik düzeylerine göre çocukların okuryazarlık becerilerini desteklemek için yaptıkları okuma etkinliklerini belirlemeyi amaçlamışlardır. Araştırma sonucunda üst sosyoekonomik düzeyde yer alan ebeveynlerin, alt sosyoekonomik seviyedeki ebeveynlere göre çocuklarına daha fazla kitap okudukları ve sıkığının her gün olduğunu bulmuşlardır. Bu araştırmada da üst sosyoekonomik düzeyde yer alan ailelerin çocuklarına daha fazla kitap okudukları görülmektedir. Benzer şekilde (Uluğ, 2018) yüksek sosyal desek algısına sahip olan ebeveynlerin, düşük sosyal destek algısı olan ebeveynlere kıyasla, çocuklarına daha olumlu ev erken okuryazarlık özellikleri sağladığını bulmuştur. Bu çalışmada da benzer şekilde çocuğu okula başladıktan sonra kitap okumaya başlayan alt sosyoekonomik düzeyde ebeveynler yer almaktadır.

Alt sosyoekonomik düzeyde yer alan yerleşim yerlerinde/mahallelerde yaşayan ailelerin çocuklarının mahallelerinde kitapçı, kütüphane, kitap okuyan kişiler görme ihtimalleri düşüktür. Öğretmenlerin, öğrencilerin evlerinin yerleri nedeniyle karşılaştıkları sınırlamaların farkında olması gerekir. Alt sosyoekonomik düzeyde yer alan ebeveynlerin çocukları, evlerinde kendilerine zengin bir ev okuryazarlığı ortamı sağlanmadığı için okulda daha fazla dezavantajlı olmamalıdır (Van Vechten, 2013). Bunun yanı sıra evde çok fazla sayıda kitap olmasından ziyade kitaplarla etkileşimli olarak gerçekleştirilen etkinliklerin önemi göze çarpmaktadır. Kirby ve Hogan'e göre (2008) "evde çok sayıda kitaba sahip olmak okuryazarlık kazanımına katkıda bulunmaz; önemli olan kitaplarla yapılan şeydir "(s. 115). Çocukların okuryazarlık ve dil becerilerini geliştirmek için ev okuryazarlığı ortamının ne kadar önemli olduğunu anlamak önemlidir. Ev okuryazarlığı ortamı, çeşitli kitap ve metinlere sahip bir yer ortamın ötesinde, çocukların okuduğu, okuduğunu gözlemlediği, ortak kitap okuma etkinliklerine katıldığı, kitap okuma davranışları hakkında bir anlayış geliştirdiği ve dil becerilerini geliştirdiği bir yer olmalıdır.

Okuryazarlık güçlü bir araçtır. Öğretmenler, eşit olmayan geçmişlerden ve ev ortamlarından gelen öğrenciler için öğrenme ortamını dengeleme fırsatına sahiptir. Öğretmenlerin, tüm öğrencilerin benzer hissettiği ev ortamlarından geldiğini varsaymamaları gerekmektedir (Van Vechten, 2013). Bu durum Kucer (2009) tarafından "bu durumlarda çocukların okulda ne öğrendikleri değerlendiriliyor ancak evde öğrendikleri ve sınıf ortamına ne getirdikleri değerlendirilmiyor." şeklinde ifade edilmiştir. Bu araştırma sonuçlarından hareketle, ailelerin erken okuryazarlık becerileri ve uygun ev ortamı oluşturma konusunda bilinçlendirilmesi önerilebilir. Ayrıca ebeveynlere yönelik ev okuryazarlığı ve aile okuryazarlığı programları geliştirilmelidir. Bunun yanı sıra öğretmenlere ev okuryazarlığı ortamlarına yönelik olarak verilecek eğitimlerde, öğrencilerin farklı ev ortamlarından geldikleri ve öğretmenlerin bu eşitsizliği dengeleme fırsatına sahip oldukları vurgulanmalıdır.

\section{Kaynaklar}

Akkuş, S., Yılmazer, Y., Şahinöz, A., ve Sucaklı, İ. (2015). 3-60 ay arası çocukların televizyon izleme alışkanlıklarının incelenmesi. Hacettepe Üniversitesi Sağlık Bilimleri Fakültesi Dergisi. 1(2), 351-360.

Akyüz, E. (2016). Okul öncesi dönem çocuklarının kendiliğinden ortaya çıkan okuryazarlık becerilerinin gelişimi ve ev okuryazarlık ortamı ile ilişkisi. Doktora tezi, Hacettepe Üniversitesi, Ankara.

Akyüz, E., ve Doğan, Ö. (2017). Ev okuryazarlık ortamı: tanımları, boyutları ve kendiliğinden ortaya çıkan okuryazarlık becerilerinin gelişimindeki rolü. Hacettepe Üniversitesi Sağlık Bilimleri Fakültesi Dergisi, 4(3), 38-57. 
Altun, D., ve Tantekin-Erden, F. (2015). Okuryazarlık süreci açısından ev-içi okuryazarlık ortamı: Çocukların ilkokula başlamadan önce ev-içi okuryazarlık deneyimlerinin incelenmesi. In 14th National Primary Teacher Education Symposium (USOS), Bartın, Türkiye.

Altun, D., Tantekin Erden, F., ve Snow, C. E. (2016). Filizlenen okuryazarlık: Okul öncesi dönem ses ve yazı farkındalığı becerilerini besleyen ev-içi kaynakların incelenmesi. İçinde Ö. Demirel ve $S$. Dinçer (Eds.). Eğitim Bilimlerinde Yenilikler ve Nitelik Arayışı (s. 505-529). Ankara: Pegem Akademi Yayınevi.

Audet D., Evans, M. A., Williamson, K., \& Reynolds, K. (2008). Shared book reading: Parental goals across the primary grades and goal-behavior relationships in junior kindergarten. Early Education and Development, 19(1), 112-137.

Baydar, N., Küntay, A. C., Yağmurlu, B., Aydemir, N., Çankaya, D., Göksen, F., ve Cemalcilar, Z. (2014). "It takes a village" to support the vocabulary development of children with multiple risk factors. Developmental Psychology, 50(4), 1014.

Beals, D. E., De Temple, J. M., \& Dickinson, D. K. (1994). Talking and listening that support early literacy development of children from low-income families. In D. K. Dickinson (Ed.), Bridges to literacy: Children, families, and schools (p. 19-40). Blackwell Publishing.

Bingham, G. E. (2007). Maternal literacy beliefs and the quality of mother-child book-reading interactions: assoications with children's early literacy development. Early Education and Development, 18(1), 23-49.

Britto, P. R. (2001). Family literacy environments and young children's emerging literacy skills. Reading Research Quarterly, 36(4), 346-347.

Burgess, S. R., Hecht, S. A., \& Lonigan, C. J. (2002). Relations of the home literacy environment (HLE) to the development of reading-related abilities: A one-year longitudinal study. Reading Research Quarterly, 37, 408-426.

Cohen, L., Manion, L., \& Morrison, K. (2005). Research methods in education. British Library Cataloguing in Publication Data. Master e-book ISBN.

Cunningham, A. E., \& Zibulsky, J. (2011). Tell me a story: Examining the benefits of reading. S. B. Neuman ve D. K. Dickinson (Eds.). Handbook of Early Literacy Research (Cilt. 3, s.397-411). New York: Guilford Press.

Curenton, S. M., \& Justice, L. M. (2008). Children's preliteracy skills: Influence of mothers' education and beliefs about shared-reading interactions. Early Education and Development, 19(2), 261283.

Deckner, D. F., Adamson, L. B., \& Bakeman, R. (2006). Child and maternal contributions to shared reading: Effects on language and literacy development. Journal of Applied Developmental Psychology, 27, 31-41.

Dickinson, D. K., \& Tabors, P. O. (1991). Early literacy: Linkages between home, school and literacy achievement at age five. Journal of Research in Childhood Education, 6(1), 30-46.

Dulay, K. M., Cheung, S. K., \& McBride, C. (2018). Environmental correlates of early language and literacy in low-to middle-income Filipino families. Contemporary Educational Psychology, 53, 45-56.

Early, D. M., Maxwell, K. L., Burchinal, M., Alva, S., Bender, R. H., Bryant, D., Cai, K. \& Zill, N. (2007). Teachers' education, classroom quality, and young children's academic skills: Results from seven studies of preschool programs. Child Development, 78(2), 558-580.

Ergül, C., Sarıca, A. D., Akoğlu, G., \& Karaman, G. (2017). The home literacy environments of Turkish kindergarteners: Does SES make a difference?. International Journal of Instruction, 10(1), 187-202.

Goodman, Y. (2001). The development of initial literacy. In E. Cushman, E.R. Kintgen, B.M. Kroll \& M. Rose (Eds.) Literacy: A critical sourcebook (pp. 316-324). Boston: Bedford/St. Martin's.

Heath, S.B. (1982). What no bedtime story means: Narrative skills at home and school. Language in Society, 11, 49-76.

Jellinek, M., Patel, B. P., \& Froehle, M. C. (2002). Bright futures in practice. Mental health practive guide (Vol. 1). Arlington VA: National Center for Education in Maternal and Child Health. 
Kirby, J. R., \& Hogan, B. (2008). Family literacy environment and early literacy development. Exceptionality Education International, 18(3), 112-130.

Kucer, S.B. (2009). Dimensions of literacy: A conceptual base for teaching reading and writing in school settings. (3rd Ed.). Mahwah, NY: Erlbaum.

Küntay, A. (2013). Learning to talk about chairs (and other things: Emergence and development of language-and-communication in children). Inaugural address. Utrecht University: Netherlands.

Larson, J. \& Marsh, J. (2005). Making literacy real: Theories and practices for learning and teaching. Thousand Oaks, CA: Sage.

Leseman, P.P.M. (1993). How parents provide young children with access to literacy. In L. Eldering \& P. Leseman (Eds.), Early intervention and culture (pp. 149-171). Paris: UNESCO.

Leseman, P. P. M., \& de Jong, P. F. (1998). Home literacy: Opportunity, instruction, cooperation and social-emotional quality predicting early reading achievement. Reading Research Quarterly, 33(3), 294-318.

Martini, F., \& Sénéchal, M. (2012). Learning literacy skills at home: Parent teaching, expectations, and child interest. Canadian Journal of Behavioural Science/Revue canadienne des sciences $d u$ comportement, 44(3), 210.

Mason, J.M. (1992). Reading stories to preliterate children: A proposed connection to reading. In P.B. Gough, L.C. Ehri, \& R. Treiman (Eds.), Reading acquisition (pp. 215-241). Hillsdale, NJ: Erlbaum.

Miles, M. B., \& Huberman, A. M. (1994). Qualitative data analysis: An expanded sourcebook (2nd ed.). Thousand Oaks, CA: Sage Publications.

Miles, M. B., Huberman, A. M. \& Saldaña, J. (2014). Qualitative data analysis : A methods sourcebook (4th ed.). California: Sage Publications.

Moses, A. M., \& Duke, N. K. (2008). Portrayals of print literacy in children's television programming. Journal of Literacy Research, 40(3), 251-289.

Norman, R. C. (2007). Do Parents' Literacy Beliefs and Home Literacy Experiences Relate to Children's Literacy Skills?. (Master Disertation). Brigham Young Universtiy

Onchwari, G., \& Kenngwe, J. (2010). Teacher mentoring and early literacy learning: a case study of a mentor-coach initiative. Early Childhood Education Journal, 37, 311-317.

Otto, B. (2008). Language Development in Early Childhood. (3rd Ed.). Upper Saddle River, New Jersey: Merrill.

Özbek Ayaz, C. (2015). Ailelerin, okul öncesi dönemdeki çocuklarının okuryazarlık becerilerini desteklemek için kullandıkları okuryazarlık uygulamalarının incelenmesi: Tekirdağ ili örneği (Master's thesis, Çanakkale On sekiz Mart Üniversitesi Eğitim Bilimleri Enstitüsü).

Öztürk, C., ve Karayağız, G. (2007). Çocuk ve televizyon. Journal of Anatolia Nursing and Health Sciences, 10(2).

Puranik, C. S., Phillips, B. M., Lonigan, C. J., \& Gibson, E. (2018). Home literacy practices and preschool children's emergent writing skills: An initial investigation. Early Childhood Research Quarterly, 42, 228-238.

Purcell-Gates, V., \& Dahl, K. L. (1991). Low-SES children's success and failure at early literacy learning in skills-based classrooms. Journal of Reading Behavior, 23(1), 1-34.

Senechal, M., LeFevre, J-A., Thomas, E. M., \& Daley, K. E. (1998). Differential effects of home literacy experiences on the development of oral and written language. Reading Research Quarterly, 33(1), 96-116.

Senechal, M., \& LeFevre, J. (2002). Parental involvement in the development of children's reading skill: A five-year longitudinal study. Child Development, 73(2), 445-460.

Sim, S., Berthelsen, D., Walker, S., Nicholson J., \& Fielding-Barnsley, R. (2014). A shared reading intervention with parents to enhance young children's early literacy skills. Early Child Development and Care, 184:11, 1531-1549. 
Uluğ, E. (2018). Okul Öncesi Eğitim Kurumuna Devam Eden ve etmeyen 12-36 aylık çocukların ev erken okuryazarlık ortam özelliklerinin incelenmesi. Yüksek lisans tezi. Ankara Üniversitesi Eğitim Bilimleri Enstitüsü Ilköğretim Anabilim Dalı Okul Öncesi Eğitim Programı. Ankara.

Van Vechten, D. (2013). Impact of home literacy environments on students from low socioeconomic status backgrounds. Masters Thesis. St. John Fisher College, School of Arts and Sciences, New York.

Wagner, R.K., Torgesen, J.K., \& Rashotte, C. A. (1994). Development of reading-related phonological processing abilities: New evidence of bidirectional causality from a latent variable longitudinal study. Developmental Psychology, 30(1), 73-87.

Warren-Leubecker, A., \& Carter, B.W. (1988). Reading and growth in metalinguistic awareness: Relations to socioeconomic status and reading readiness skills. Child Development, 59(3), 728-742.

Watson, R. (1989). Literate discourse and cognitive organization: Some relations between parents' talk and 3-year-olds' thought. Applied Psycholinguistics, 10 (2), 221-236.

Weigel, D. J., Martin, S. S., \& Bennett, K. K. (2006). Mothers' literacy beliefs: Connections with the home literacy environment and pre-school children's literacy development. Journal of Early Childhood Literacy, 6(2), 191-211.

Wells, G. (1985a). Language development in the pre-school years. Cambridge, England: Cambridge University Press.

Wells, G. (1985b). Preschool literacy-related activities and success in school. In D.R. Olson, N.

Yin, R. K. (2017). Case study research and applications: Design and methods. Sage publications.

\section{Introduction}

\section{Extended Abstract}

Literacy is an acquired, socially created and guided tool that enables people to think, communicate, research and interact with society. The definition of literacy that guides this study has been handled socioculturally based on the roles of the society and cultural differences. The home is the groundwork for language and literacy skills for many children. Exposure to texts through materials such as newspapers, magazines, books in the home environment, joint literacy activities between generations and preparation for reading and writing are possible with effective home literacy environments. The development of early literacy skills in a child occurs long before starting school. For the development of these skills, home literacy environments in which children grow up are considered important. Home literacy can be expressed as the number of books the child is exposed to in the home environment, and time spent reading and literacy activities at home. In such an environment, a culture of reading occurs in the child growing up. It is also possible that the child will acquire basic literacy skills. In this study, home literacy environments were investigated according to socio-economic level. It is thought that this research will give teachers information about students' backgrounds according to socio-economic level. It can also give information about what kind of home environment students came to the school before the process of literacy. This issue is important; because it requires teachers to examine students' possible prejudices and expectations about their home literacy environment. With this study, home literacy environments of children at different socioeconomic levels were investigated in line with the opinions of the parents.

\section{Method}

In this study, case study was used. Within the scope of this research, parents' home literacy experiences were taken as a basis and how participant parents reflected their experiences to their children was examined with a qualitative approach. Participants consisted of 23 parents who lived in Istanbul and whose children were in preschool period. They were determined by using the maximum variation sampling method which is one of the purposeful sampling methods. In this study, parents who had different socioeconomic status (high, middle, lower) were included because the socioeconomic levels of the parents could influence home literacy experiences. The study group was determined to provide diversity in terms of socioeconomic status. Twenty-two of the interviewed 
parents were mothers and one was a father. Seven of the parents had at a lower socioeconomic status, eight of the parents had a middle socioeconomic status, and eight of the parents had a higher socioeconomic status.

Data were collected through a semi-structured interview form. Questions in the interview form were collected under five themes: time spent at home, literacy studies, possession of a library, book selection, library visits. Data was analysed through content analysis technique.

\section{Result and Discussion}

When parents' time spent with their children at home was evaluated, it was observed that they usually spent time by playing games, doing homework, watching a tablet or watching TV. It was also observed that $74 \%$ of the 23 parents who participated in the study read books to their children and $6 \%$ of the 23 parents did not. In this study, only four of the parents read books to their children starting from an early age. Only eight of the parents made interactive reading activities enabling book reading meaningful.

In this study, it was concluded that $57 \%$ of the parents performed preparatory writing activities when their children started school, 30\% performed preparatory writing activities starting from an early age, and $13 \%$ did not perform these activities. It was observed that the parents who performed preparatory activities for writing together with their children do activities such as playing play dough, and activities that develop hand-arm muscles, such as painting work, pencil holding, line work and cutting.

In this study, $83 \%$ of the parents stated that their children did not see a library and $17 \%$ of them stated that theirs did. Parents of those who visited the library stated that their children went to the library either on a school trip or for another activity and that their children loved the library. It was concluded that $30 \%$ of the children of the parents who participated in this study had a library at home, $44 \%$ did not have a library at home, and $26 \%$ used a basket or shelf even if they did not have a library at home. $96 \%$ of the parents who participated in the study stated that they bought books for their children and $4 \%$ stated that they were given books by others and therefore they did not need to buy them. 